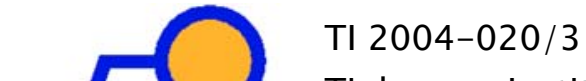

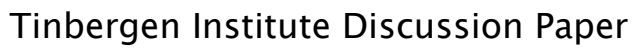 \\ $\square$ Environmental Regulation and International Trade
}

\author{
Abay Mulatur \\ Raymond J.G.M. Florax ${ }^{2,3}$ \\ Cees A. Withagen $2,4,5$
}

' Department of Economic History, London School of Economics, London, UK,

2 Faculty of Economics and Business Administration, Vrije Universiteit Amsterdam, The Netherlands,

3 Regional Economics Applications Laboratory (REAL), University of Illinois, Urbana-Champaign, USA,

${ }^{4}$ Department of Economics, Tilburg University, The Netherlands,

5 Tinbergen Institute. 


\section{Tinbergen Institute}

The Tinbergen Institute is the institute for economic research of the Erasmus Universiteit Rotterdam, Universiteit van Amsterdam, and Vrije Universiteit Amsterdam.

Tinbergen Institute Amsterdam

Roetersstraat 31

1018 WB Amsterdam

The Netherlands

Tel.: $\quad+31(0) 205513500$

Fax: $\quad+31(0) 205513555$

Tinbergen Institute Rotterdam

Burg. Oudlaan 50

3062 PA Rotterdam

The Netherlands

Tel.: $\quad+31(0) 104088900$

Fax: $\quad+31(0) 104089031$

Please send questions and/or remarks of nonscientific nature to driessen@tinbergen.nl.

Most TI discussion papers can be downloaded at http://www.tinbergen.nl. 


\title{
Environmental regulation and international trade: \\ Empirical results for the manufacturing industry in Germany, the \\ Netherlands and the US, 1972 - 1992
}

\author{
Abay Mulatu \\ Department of Economic History, London School of Economics, London, UK \\ Raymond J.G.M. Florax \\ Department of Spatial Economics, Free University, Amsterdam, The Netherlands, and \\ Regional Economics Applications Laboratory (REAL), University of Illinois, \\ Urbana-Champaign, USA \\ Cees A. Withagen ${ }^{*}$ \\ Department of Spatial Economics, Free University, Amsterdam, and \\ Department of Economics, Tilburg University, Tilburg, The Netherlands
}

Key words: trade, competitiveness, environmental policy, pollution abatement, pollution haven JEL code: F14, L50, Q28

\begin{abstract}
We empirically investigate the responsiveness of international trade to the stringency of environmental regulation. Stringent environmental regulation may impair the export competitiveness of 'dirty' domestic industries, and as a result, 'pollution havens' emerge in countries where environmental regulation is 'over-lax.' We examine the impact of pollution abatement and control costs on net exports in order to grasp this phenomenon. Theoretically, our analysis is related to a general equilibrium model of trade and pollution nesting the pollution haven motive for trade with the factor endowment motive. We analyze data on two-digit ISIC manufacturing industries during the period 1977-1992 in Germany, the Netherlands and the US, and show that trade patterns in 'dirty' commodities are jointly determined by relative factor endowments and environmental stringency differentials.
\end{abstract}

\footnotetext{
* Corresponding author. Department of Spatial Economics, Faculty of Economics, Free University Amsterdam, De Boelelaan 1105, 1081 HV Amsterdam, The Netherlands. Email: cwithagen@feweb.vu.nl
} 


\section{Introduction}

Environmental policymaking, be it unilateral or multilateral, is riddled with competitiveness concerns. Labor unions and industry worry about uneven environmental standards across jurisdictions resulting in distortions of the 'level playing field' in the market. ${ }^{1}$ Environmentalists are apprehensive of the emergence of 'pollution havens' in the South, and the potential of a 'downward spiral' in setting environmental standards. A 'race-to-the-bottom' can be evoked by competitiveness concerns inducing governments to undercut each other's environmental standards. ${ }^{2}$

The pivotal issue at stake is whether domestic environmental regulation impairs the competitiveness of domestic industries, especially the pollution-intensive industries. The general conclusion emerging from the literature on this topic seems to be rather uniform. Initially, in their early comprehensive account of the empirical literature, Jaffe et al. (1995, p. 157) conclude that "[o]verall, there is relatively little evidence to support the hypothesis that environmental regulation has a large adverse effect on competitiveness ...." Evidence from recent studies suggests this conclusion should be taken with care. Recent studies do occasionally find a negative correlation between trade and environmental stringency, although the findings do not seem to be particularly robust. Recent reviews therefore continue to argue that “ ... the costs imposed by tighter pollution regulation may not be a major determinant of trade patterns" (Copeland and Taylor, 2003, p. 220; see also Mulatu, Florax and Withagen 2003).

Concisely, the literature breaks up in two types of studies. One group of studies investigates crosscountry trade flows on the basis of country characteristics and a measure of relative stringency of environmental regulation (e.g., Tobey 1990; Diakosavvas 1994; van Beers and van den Bergh 1997; Xu 2000; Harris, Kònyà and Màtyàs 2002). The evidence for a negative impact of environmental

\footnotetext{
${ }^{1}$ Examples include the competitiveness concerns raised in relation to the unilateral introduction of a carbon tax in the Netherlands, and the discussion about the North American Free Trade Agreement (NAFTA) in the US, where opponents argued that differential environmental standards in Canada, Mexico and the US will result in massive capital flight and loss of jobs in the US. (See, for instance, Joseph Stiglitz' recent contribution to this discussion in the New York Times of January 6, 2004.)Similarly, in a multilateral setting, a proposal to implement a uniform cross-country $\mathrm{CO}_{2}$ tax in the European Union has been marred by competitiveness concerns and it is still under discussion (see, e.g., Jeppesen 2002).

${ }^{2}$ The concern for a sequential process of undercutting standards was one of the main reasons for the debacle of the Seattle trade liberalization round of the World Trade Organization (WTO) in 1999.
} 
stringency on international trade flows in these studies is at best mixed. Moreover, their differential results cannot be satisfactorily explained by corresponding differences in theoretical and methodological design, such as a Heckscher-Ohlin versus a gravity-type setup, bilateral versus multilateral trade flows, or the use of cross-section versus panel data (see Mulatu 2004, for details). Another group of studies employs some variant of the cross-commodity equation of the standard Heckscher-Ohlin factor endowment model, with factor intensities and a measure of environmental compliance costs explaining net exports (Kalt 1988; Grossman and Krueger 1993; Osang and Nandy 2000; Levinson and Taylor 2001; Ederington and Minier 2003). These studies by and large document corroborating evidence for the hypothesized negative correlation between compliance costs of environmental regulation and export performance of 'dirty' industries, but they are typically confined to cross-industry trade flows pertaining to the US. The two most recent studies also account for endogeneity of environmental policy, showing that endogeneity bias implies an increase in the magnitude of the negative effect, maintaining comparable levels of statistical significance.

This paper adds to the above literature in a number of respects. First, we assert that empirical environment/trade studies are as a rule not very scrupulously deduced from the traditional HeckscherOhlin perspective on international trade. We try to build on some new recent theoretical insights on international trade flows, environmental policy, relative factor intensities and relative factor abundance, as explained in several seminal contributions by Copeland and Taylor (see e.g., Copeland and Taylor 2003). Admittedly, the theory cannot readily be applied because its framework is rather restrictive with respect to the number of sectors and production factors, as is common in most Heckscher-Ohlin theories. Nevertheless, we try to embody the main ideas into our modeling. Second, although we stick to the traditional exogeneity assumptions in linking environmental regulation to export competitiveness, our analysis provides several empirical novelties. We extend the analysis that is typically confined to the US $\mathrm{US}^{3}$ to a broader set of countries by including data on Germany, and the Netherlands. We also put considerable emphasis on building a database that covers a sufficiently large time-period at a reasonably low level of sectoral aggregation. The data we use stretch from 1972 to

\footnotetext{
${ }^{3}$ Bouman (1998) investigates Germany and the US, but his research is concerned with the relæed issue of the link between stringency of environmental regulation and foreign direct investment.
} 
1992, and they are based on a two-digit level classification of the manufacturing industry. Finally, despite the data characteristics, we use the fixed and random effects models typically employed in this literature. However, we also provide results for the so-called time-series cross-section (TSCS) estimator that allows for heteroskedasticity and contemporaneous autocorrelation. The TSCS estimator is typically underutilized in this area of research, although it fits the data characteristics quite well.

The remainder of this paper is organized as follows. Section 2 outlines the theoretical HeckscherOhlin basis for empirical research on environment/international-trade models, and discusses the setup of our empirical model. In Section 3, we present the data and some initial exploratory analyses. Section 4 presents and discusses the estimation results, and Section 5 provides conclusions and ramifications.

\section{Theory and empirical model}

Arguably, considerable differences in model specification exist in cross-industry trade studies on environmental regulation. Because of a rather 'loose' link to theory, and lack of theoretical guidance in determining the appropriate specification, both the estimator (simple OLS, fixed or random effects, accounting for endogeneity of explanatory variables) and the set of conditioning variables vary considerably across studies. ${ }^{4}$ All empirical studies, however, are rooted in standard international trade theory, using the general empirical trade equation $T=A^{\prime} \beta+\gamma E+\varepsilon$, where $T$ is a vector of a country's net exports of commodities, $A^{\prime}$ a matrix of factor intensities, $E$ a measure of environmental compliance costs, $\beta$ and $\gamma$ (a vector of) coefficients to be estimated, and $\varepsilon$ a vector of error terms.

Specifically, the specifications in empirical environment/international-trade studies are driven by a combination of the standard Heckscher-Ohlin theory and the insights derived from theoretical models on environmental policy and international trade - which are in themselves based on the HeckscherOhlin framework. The Heckscher-Ohlin flavor of the models is visible in the notion that industry

\footnotetext{
${ }^{4}$ Obviously, the two issues are often intrinsically linked. For instance, Levinson and Taylor (2001) exclude factor intensities as potential determinants oftrade arguing that their effect will be picked up by fixed terms in a panel data setting.
} 
characteristics are potentially relevant. This follows from the classical inference of the HeckscherOhlin model that countries focus on the production and exports of those commodities that intensively use factors abundant in supply (see, e.g., Harkness 1983; Deardorff 1984). The environment/trade feature of the models becomes evident in the recognition that stringent regulation, by way of increasing industry costs, raises imports and/or decreases exports of those industries in which production entails considerable emission of pollutants. Stringent environmental regulation is hence viewed as a source of comparative disadvantage in pollution intensive industries (see, e.g., Siebert 1974, 1987; Pethig 1976; Copeland and Taylor 1994, 1995).

We follow the tradition of adopting the Heckscher-Ohlin framework as, admittedly, a rather informally inferred basis for the empirical specification of our model. However, we specifically base our empirical model on newly attained insights in a Heckscher-Ohlin based general equilibrium model of trade and pollution presented by Antweiler, Copeland and Taylor (2001), and elaborated in Copeland and Taylor (2003). A novel feature of this model is that it includes both the pollution haven and the factor-abundance motive as special cases. These contributions show that in a two-country model, stylistically identified as North and South with the North being capital abundant and maintaining a higher environmental standard, the two motives for trade work in opposite directions. A stringent pollution policy lowers output of the capital-intensive dirty good. Concurrently, greater abundance of capital raises output. Hence, while the factor abundance motive can be overturned due to pronounced differences in environmental policies, it is also possible for the factor abundance motive to maintain its dominance if such differences are small.

The implication of this theoretical inference for the empirical model is that, since rich countries tend to be capital abundant and generally have more strict regulation, the two opposing forces on trade patterns are likely to be correlated. In determining the location of capital-intensive dirty good production, one force pulls it to the rich country (the North), while the other force drives it out of the North. Hence, an empirical model of trade in dirty goods should take into account not only stringency of environmental policy, but also factor endowments. In our empirical models, we will not do this explicitly, because we describe three countries that all belong to the North. In the interpretation of the empirical results, however, we will take the considerations outlined above into account. 
The theoretical model further suggests some additional hypotheses that should be amply considered in the empirical analysis. First, the fact that trade patterns are jointly determined by relative factor abundance and differences in environmental stringency implies that environmental policy should be sufficiently strict for it to have a measurable effect. Second, if a good is relatively laborintensive and at the same time relatively pollution-intensive, it is likely to be produced in, and exported by, the South, which is characterized by laxer environmental regulation. The converse of course also holds true.

The intersection of a cross-country setting with a cross-commodity model is well established in the standard empirical literature. Under certain assumptions, “... the rankings of commodities by net exports and by intensity of use of the relatively abundant factor will be identical" (Harkness 1981, p. 1044). We therefore employ an empirical specification that is similar to the standard cross-commodity equation discussed above. The empirical model relates net exports of an industry to its factor uses, as well as to capital expenditures on pollution abatement and control, and it reads as follows:

$$
N X_{i t}^{j}=f^{j}\left(M K_{i t}^{j}, S L_{i t}^{j}, U L_{i t}^{j}, R D_{i t}^{j}, P A C E_{i t}^{j}\right)+\varepsilon_{i t}^{j},
$$

where $i$ denotes an industry, $j$ a country, $t$ time, and $\varepsilon$ an error term with properties to be discussed below. We estimate (1) for each country separately, but drop the index $j$ from here on for notational convenience.

The dependent variable $N X$ measures net exports, scaled by the value of production. Scaling is customary and appropriate because of scale differences between industry groups (see, e.g., Leamer 1988). ${ }^{5}$ The explanatory variables follow more or less directly from the preceding theoretical considerations. The variable $M K$ represents gross fixed new capital formation and proxies the flow of capital services. $S L$ and $U L$ denote the flow of the services of skilled and unskilled labor, respectively. Following, among others, Branson and Monoyios (1977), Kalt (1988), and Stern and Maskus (1988)

\footnotetext{
${ }^{5}$ Large (small) industry groups use more (fewer) factor inputs, which are included as explanatory variables. The error terms and the explanatory variables are then correlated, violating the Gauss-Markov conditions. The issue of the right scaling variable is a contentious topic in the trade literature. Some consider 'trade size' appropriate (e.g., Deardorff 1984); others favor 'value of production' (e.g., Anderson 1988. We use value of production because it is the most widely used (see Grossman and Krueger 1993; Levinson and Taylor 2001).
} 
the labor flow variables are constructed by means of a standard technique from the human capital literature based on production functions. ${ }^{6}$ Finally, $R D$ denotes expenditures for research and development capturing technological differences across countries, and $P A C E$ represents capital expenditures for pollution abatement and control as a share of gross fixed new capital formation.

In a strict sense, theory requires the explanatory variables to be the technology coefficients, defined as the (amount of) input per unit of output. In practice, some use factor shares in total value added (e.g., Harkness, 1981, 1983) or factor use, i.e. the total value of each factor input (e.g., Branson and Monoyios, 1977; Stern and Maskus, 1981), as a proxy for factor intensity. The latter is a questionable proxy of relative factor intensity because it does not take account of differences (in size) across industries. However, in a multiple regression context, where the procedure takes into account (or controls for) the magnitudes of the rest of the variables in comparing the magnitude of one variable across industries, this is not necessarily problematic.

The environmental variable measures capital expenditures rather than recurrent operating costs, although the latter may more suitably reflect the year-to-year burden of compliance with pollution regulation. Because capital expenditures are spread over a number of years, the expenditure at time $t$ may not instantaneously influence the profit function, and thereby net exports of an industry. Levinson and Taylor (2001) contend that pollution abatement capital expenditures may even show a spurious positive correlation with net exports, because industries with thriving exports are more likely to make new investments, which typically have a larger abatement capital component (see also Osang and Nandy 2000; and Mulatu 2004, for a more detailed discussion). With these caveats in mind, we nevertheless opt for capital expenditures as a measure of stringency in order to be able to construct a

\footnotetext{
${ }^{6}$ Skilled labor is calculated as $S L_{i t}=\left(\bar{W}_{i t}-\widetilde{W}_{t}\right) L_{i t} / 0.10$, where $S L$ denotes skilled labor services, $\bar{W}$ the average wage in each industry, $\widetilde{W}$ the average wage in the least-paying manufacturing industry, $L$ the number of workers in each industry, and 0.10 is a discount rate. This method rests on the assumption of skilled labor services (i.e., human capital) in an industry being reflected as industry wage differentials, and hence the wages in the least-paying industry reflecting unskilled labor. Similarly, unskilled labor $(U L)$ in an industry can be calculated as the product of the number of workers empbyed in that industry and the average wage in the least paying industry. This type of calculation goes back to Griliches (1970, p. 85), who proposed a measure of human capital based on "a capitalization of the wage differentials over and above the returnsto 'raw', unskilled, or uneducated labor." The discount rate transforms the stock variable into a stream, which is similar to its use in the capitalization of a capital asset with a perpetual yield (see Chiang 1984, p. 464). Note that the actual value oflte discount rate does not affect the regression results, apart from changing the scale of the variable.
} 
comparable data series for the three countries we consider. We also find it consoling that the capital expenditure variable is not suspect to unduly rejecting the null-hypothesis of no correlation between environmental stringency and net trade flows if the correlation is effectively zero.

\section{Data and exploratory analysis}

Our dataset pertains to nine two-digit ISIC manufacturing industries, for Germany, the Netherlands, and the US, over the time-period 1977-1992. Table 1 provides the definitions of the industries for various industrial classification systems. Details about how we handled the incompleteness of the panel are described in the notes to Table 2. Monetary values are converted into 1996 US dollars using the US GDP deflator, and Purchasing Power Parity exchange rates to convert the German and Dutch currencies. The data are taken from various OECD publications, except for the data on pollution abatement capital expenditures. These are taken from Bouman (1998), who collected the data from the respective national statistics agencies. See the Appendix for details.

$<$ Table 1 about here $>$

For the industries described in Table 1, a common classification in the environment/trade literature uses the criteria of the industry being pollution-intensive (PI) or non-pollution-intensive (NPI), as well as being resource-based (RB) or non-resource-based (NRB; i.e., non-natural-resource-intensive). The rationale behind this categorization is to account for industry heterogeneity according to the expected effect of environmental regulation on industry competitiveness. We expect the effect to be most pronounced for PI and NRB industries (van Beers and van den Bergh 1997).

The categorization of industries as PI is usually based on the emission-intensity per dollar of output, or pollution abatement and control expenditures as a percentage of sales or value added. Our classification in Table 1 is based on Low and Yeats (1992), who identify PI industries as industries incurring pollution abatement and control costs of a minimum of $1 \%$ of the sales value in 1988 . The resource base classification reflects the natural-resource intensity of industries. Non-resource based 
industries are generally geographically 'footloose.' The resource base classification in Table 1 is based on UNIDO (1982). ${ }^{7}$

$<$ Table 2 about here $>$

Table 2 presents descriptive statistics of the data for the two-digit ISIC manufacturing industries for each of the three countries. Pollution abatement cost as a share of gross new fixed capital formation for the average 2-digit ISIC manufacturing industry is highest in the US and lowest in the Netherlands. For trade of the manufacturing industry, we observe that while both Germany and the Netherlands are net exporters, the US is a net importer.

$<$ Figure 1 about here $>$

The sectoral variation of PACE and net exports across countries is depicted in Figure 1. It shows that there is no clear-cut negative association between PACE and net exports. We find bivariate correlations of $0.19,0.49$ and -0.11 , for Germany, the Netherlands and the US, respectively. Examples of contrary 'evidence' are therefore numerous. For instance, each of the three countries is a significant importer in ISIC 32 and 33, despite the relatively low PACE in these sectors. The PACE levels in ISIC 35 and 37 are relatively high in all countries considered. Nevertheless, Germany is a significant net exporter in both sectors. This result is in line with the results of cross-country comparisons with respect to shares in 'dirty' industry production. For instance, Copeland and Taylor (2003) present evidence that many of the most environmentally stringent countries are among the most prominent producers and exporters of dirty goods. Germany actually has the highest share of world trade in dirty goods in 1988, followed by the US, while the Netherlands comes in sixth.

$<$ Figure 2 about here $>$

Does the above inference change if we take variations in factor intensity across sectors into

\footnotetext{
${ }^{7}$ An additional complication is that Low and Yeats (1992), and UNIDO (1982) use the threedigit Standard International Trade Classification (SITC). Detals about the conversion to two-digit ISIC industries are presented in the Appendix.
} 
account? Figure 2 provides a comparison of factor use intensity across sectors. ${ }^{8}$ From Figure 1 we know that ISIC 34-37 in Germany perform relatively well despite the relatively high PACE level. Figure 2 shows that these sectors are also relatively more intensive in their use of skilled labor. In the US, ISIC 34-35 and 37-38 perform relatively well in trade, despite their relatively higher PACE. These sectors intensively use both man-made capital and skilled labor. Sector 32, however, does poorly in exports, despite its relatively low PACE level. This sector, however, is relatively intensive in unskilled labor. Similar, although slightly less clear-cut, examples can be drawn from Figures 1-2 for the Netherlands. Without attaching undue importance to this result of our exploring the data, these analyses hint at relative factor intensity potentially being an important factor in explaining the effect of PACE on net exports. We will return to this issue in the explanatory regression analyses discussed in the next section.

\section{Estimation results}

Prior to discussing the empirical results of the general model in Section 4.2, and the for sectors with different characteristics in Sections 4.3 and 4.4, we discuss pivotal estimation issues in Section 4.1.

\subsection{Estimation issues}

For the estimation of the empirical model given in (1), we have panel data referring to nine two-digit ISIC manufacturing industries, in Germany, the Netherlands, and the US, over the time-period 19771992. We estimate separate regressions for each country. Initially we provide results for three common estimators: ordinary least squares (OLS), and the estimators for fixed and random effects models (FEM and REM, respectively). The assumptions underlying these estimators are rather restrictive. For OLS it is assumed that $\mathrm{E}\left(\varepsilon_{i t}\right)=0$ for all $i$ and $t, \mathrm{E}\left(\varepsilon_{i t}^{2}\right)=\sigma^{2}$ for all $i$ and $t$, and $\mathrm{E}\left(\varepsilon_{i t} \varepsilon_{j s}\right)=0$ for all $s \neq t$ or all $i \neq j$. This set of assumptions makes OLS identical to the cross-sectional data analyses

\footnotetext{
${ }^{8}$ Factor use is expressed as a share in Figure 2, as opposed to the value figures in Table 2 that will also be used in the regressions, in order to correct for size differences across industries and countries.
} 
predominantly employed in this literature. Simple as well as pooled cross-sectional data analyses using OLS ignore heterogeneity across units with respect to unobservable characteristics, either for lack of variation or as a deliberate modeling choice. This may cause the OLS estimator to be biased. ${ }^{9}$ The results for the OLS estimator are reported in the first three columns of Table 3.

$<$ Table 3.about here $>$

The result of the Lagrange multiplier (LM) test indicates that the hypothesis of homoskedasticity is rejected, and OLS is therefore inefficient.

The most common technique accounting for heterogeneity in panel data are the FEM and REM estimators. They account for heterogeneity across units, by means of decomposing the effects of unobservable factors into effects specific to cross-sectional units, to time-periods, and to both crosssectional units and time-periods (Hsiao 1986, p. 97). These models are used in some of the more recent contributions to the environment/trade literature (Ederington and Minier 2003; Levinson and Taylor 2001; Osang and Nandy 2000). Formally, the fixed and random effects variants of equation (1) are given by:

$$
N X_{i t}=\beta_{0 i}+\beta_{1} M K_{i t}+\beta_{2} S L_{i t}+\beta_{3} U L_{i t}+\beta_{4} R D_{i t}+\beta_{5} P A C E_{i t}+\varepsilon_{i t}
$$

where $\beta_{0 i}$ is a time-invariant group specific attribute, and $\varepsilon_{i t}$ a classical disturbance with $\mathrm{E}\left(\varepsilon_{i t}\right)=0$ and $\mathrm{E}\left(\varepsilon_{i t}^{2}\right)=\sigma^{2}$. Whereas in the fixed effects model the coefficient $\beta_{0 i}$ is taken as fixed, in the random effects model $\beta_{0 i}$ is treated as a random variable. So the random effects model splits this

\footnotetext{
${ }^{9}$ Hsiao (1986, pp. 6-7) demonstrates the occurrence of heterogeneity bias in slope coefficients, when omitting group-specific intercepts to account for heterogeneous crosssectional units in panel data analyses. In a simple cross-section analysis, the problem arising from unspecified heterogeneity is similar. The source of the problem is heterogeneity across units with respect to some relevant but unmeasured characteristic that is correlated with the included explanatory variables. A good example of this is the potential bias in crossindustry estimates of the effect of environmental regulation on trade flows, arising from erroneously ignoring the heterogeneity with respect to natural resource intensity (emphasized by Gpeland and Taylor 2003, Ch. 7, p. 36). The industries are heterogeneous with respect to their reliance on natural resources, which are productive inputs that are correlated with pollution abatement costs, but natural resource intensity is not included irthe regression.
} 
attribute into a 'mean intercept' $\beta_{0}$, and a group-specific disturbance $\mu_{i}$ that forms part of the error $\varepsilon_{i t}+\mu_{i}$, where, $\mathrm{E}\left(\mu_{i}\right)=0, \mathrm{E}\left(\mu_{i}^{2}\right)=\sigma_{\mu}^{2}, \mathrm{E}\left(\mu_{i} \mu_{j}\right)=0$ for $i \neq j$, and $\mathrm{E}\left(\varepsilon_{i} \mu_{j}\right)=0 .^{10}$

While the fixed and random effects models provide considerable advantage in handling heterogeneity inherent in cross-sectional units, each has its own caveats and they can produce quite different results. The issue of preference of one over the other is highly debated. It is clear though that allowing the unit-specific effect $\left(\beta_{0 i}\right)$ to be correlated with the other regressors, as in the fixed effects model, may be attractive in comparison to the assumption that the random effects are uncorrelated with the explanatory variables. The fixed effects model is, however, inferior to the random effects model in terms of degrees of freedom, which is a crucial issue in practice (see, e.g., Hsiao 1986, and Greene 2000).

The estimation results using the FEM and the REM estimator are reported in the last six columns of Table 3. There are important differences between the two models in terms of the sign and significance of the estimated coefficients. The specification tests show that the fixed effects model is to be preferred over the pooled cross-section and the random effects models. In the fixed effects specification virtually none of the coefficients is significant. This is not uncommon, and most likely due to a high correlation between the fixed effects and the continuous explanatory variables.

The FEM and REM estimators can, however, be criticized for not having appropriate (asymptotic) properties because we have a dataset comprising a relatively long time-series for a relatively small number of cross-sections. The so-called time-series/cross-section (TSCS) estimator is an attractive alternative, also because it has greater flexibility in modeling stochastic error process (Greene 2000, p. 593). We pool the time series of the different cross-sectional units (i.e., nine sectors in the case of Germany and the US, and eight in the case of the Netherlands), but we estimate separate regressions for each country. Formally, the model looks as:

$$
N X_{i t}=\beta_{0}+\beta_{1} M K_{i t}+\beta_{2} S L_{i t}+\beta_{3} U L_{i t}+\beta_{4} R D_{i t}+\beta_{5} P A C E_{i t}+\varepsilon_{i t}
$$

\footnotetext{
${ }^{10}$ Fixed and random effects models can also include an additional groupinvariant period-specific effect (i.e., the so-called 'two-way' variant). We report the results for the 'oneway' variant only because the results of the two-way variant are virtually identical.
} 
Several variants can be operationalized based on differing assumptions for the stochastic error component. Because the hypothesis of homoskedasticity is rejected (see Table 3), and correlation across sectors is likely, we use two variants. The first variant allows for heteroskedasticity across sectors, $\mathrm{E}\left(\varepsilon_{i t}^{2}\right)=\sigma_{i i}$, and the second variant combines groupwise heteroskedasticity with contemporaneous correlation among sectors, $\mathrm{E}\left(\varepsilon_{i t}^{2}\right)=\sigma_{i i}$ and $\mathrm{E}\left(\varepsilon_{i t} \varepsilon_{j t}\right)=\sigma_{i j}$, where $i$ and $j$ represent different sectors. We use a two-step Generalized Least Squares (GLS) estimator that produces maximum likelihood estimates (see Greene 2000, Ch. 15). ${ }^{11}$

\subsection{General model and cross-country differences}

The estimation results for the two variants of model (3) are presented in Table 4. Likelihood Ratio tests with respect to heteroskedasticity and cross-correlation, and the combined test for heteroskedasticity and cross-correlation (see note $\mathrm{d}$ to Table 4) are clearly rejected, and the last three columns of Table 4 therefore show the results of the preferred specification.

$<$ Table 4 about here $>$

The sign and statistical significance of the coefficient estimates are satisfactory, except for the PACE variable. The coefficient of PACE has the expected sign for Germany and the US, and it is highly significant in the case of the US. For the Netherlands, however, PACE has a counterintuitive positive effect and it is significantly different from zero.

It is plausible to assume that the three countries are relatively abundant in both man-made and skilled labor as well as in high technology services (proxied by R\&D), whereas unskilled labor is relatively scarce. The factor-intensity variables are then expected to have a positive sign, except for the unskilled-labor variable, for which we expect a negative sign. Table 4 shows that this is exactly

\footnotetext{
${ }^{11}$ An obvious third variant would be to combine heteroskedasticity and crosscorrelation with autocorrelation among the disturbances. We have experimented with this variant as well, but it does not converge well, possibly due to the incomplete nature of the panel and lacking degrees of freedom. The GLS estimator for the other two variants remains unbiased, but it is not necessarily the most efficient estimator if autocorrelation is present.
} 
what occurs, except for the R\&D variable, which has the 'wrong' sign and is significantly different from zero in all cases. This finding is similar to the result documented by Kalt (1988), and the aberration may be related to omitted variables, endogeneity and/or multicollinearity. ${ }^{12}$ Ederington and Minier (2003), and Levinson and Taylor (2001) find a negative coefficient for skilled labor and a positive coefficient for unskilled labor - results that do not have an intuitive appeal. Our positive coefficient estimate for man-made capital is similar to the results of Kalt (1988), and Grossman and Krueger (1993), but it is different from the findings of Branson and Monoyios (1977), Stern and Maskus (1981), and Levinson and Taylor (2001).

Arguably, stringency of environmental regulation, relative factor abundance of a country, and sectoral differences in factor intensity jointly determine trade patterns. Copeland and Taylor (2003, Ch. 6) cogently argue along these lines:

“... for some types of industries factor endowment effects can reinforce pollution policy effects. Polluting industries which are intensive in unskilled labor or natural resources that are abundant in low income countries will be attracted to those low income countries both by factor abundance and by less stringent policy. We would therefore expect to see heterogeneity across industries as well as countries in the effects of the interaction between policy differences and factor endowments in determining trade patterns."

Multicollinearity prohibits estimating a model where (all) factor endowments and environmental policy are consistently interacted. We note, however, that the magnitude of the estimated effect of environmental stringency in the different countries is in line with the stringency of their environmental policy. In terms of stringency, PACE, the US is the most stringent, while the Netherlands is the most lax. Pollution abatement control and capital expenditures (PACE) as a percentage of total investment for the manufacturing industry amount to $5 \%$ in the US, $4 \%$ in Germany, and $3 \%$ in the Netherlands. The importance of relative factor endowments in determining trade patterns implies that PACE outlays should be substantial enough to have a measurable effect on net exports. The relatively low level of

\footnotetext{
${ }^{12}$ In general, this type of research suffers from high correlations among explanatory variables. We have tried to mitigate this problem by specifying the model in firstorder differences, which would simultaneously reduce the potential inefficiency due to serial correlation. This specification doeshowever not lead to plausible results, and it is (again) complicated by the incomplete nature of the panel (see the preceding footnote). Levinson and Taylor (2001), and Ederington and Minier (2003) discuss the implications of the endogeneity of environmental policy.
} 
PACE in the Netherlands may therefore go a long way towards explaining the positive coefficient. The latter can, however, only be taken as clear evidence for the rejection of the hypothesis that stringency of environmental regulation can be a source of comparative disadvantage in dirty goods, if one is willing to buy into the appropriateness of a one-sided statistical test. Alternatively, it has been suggested that the effect may be ironed out by the provision of government subsidies to industries that are particularly hard hit by regulation (see, e.g., van Beers and van den Bergh 1997). Arguably, the socalled 'polder model' centering on consensus and elaborate negotiations among stakeholders may also contribute to flattening out the most severe impacts of policy measures. We do, however, not find it reasonable to take the positive sign of the PACE variable as a corroboration of the Porter hypothesis, maintaining that environmental stringency and competitiveness are positively correlated because of the role of innovations and the elimination of X-inefficiency. While one can agree with a weaker interpretation of the Porter hypothesis (firms react to well-designed environmental policies by investing in innovation, thereby curtailing the burden of compliance with regulation), our model has not been designed in such a way that it would do justice to testing the Porter hypothesis.

\subsection{Variation according to pollution and natural resource intensity}

It is common practice in the environment/trade literature to split samples of observations on crosscountry and cross-commodity data for separate analyses, among other things, to account for heterogeneity across sectors. This practice is obviously in line with the preceding quote from Copeland and Taylor. Van Beers and van den Bergh (1997) and Xu (2000), for example, consider separate analyses for pollution intensive (PI), and for pollution intensive and non-resource-based (NRB) industries. We also utilize this distinction and estimate model (3) allowing the estimated coefficient of PACE to vary according to pollution intensity (see Table 5), and to pollution intensity and non-resource-base features (see Table 6).

$<$ Tables 5 and 6 about here $>$ 
Levinson and Taylor (2001) point out that one of the disquieting aspects of the few studies in the literature documenting a negative effect of pollution policy on competitiveness is that these effects are found to be weaker when the data are restricted to PI industries. Obviously, the theoretical expectation is that the effect of stringency of environmental policy is stronger for pollution intensive industries. Limited data availability and the relatively high level of sectoral aggregation make that our categorization of industries as PI or NPI is not very strict. In fact, NPI comprises a mix of both PI and NPI industries, whereas the PI category exclusively concerns pollution intensive industries, specifically the Paper and Basic Metal industries (ISIC 34 and 37; see Table A1 in the Appendix for details).

The estimation results are presented in Table 5. Misspecification tests again indicate that the heteroskedastic cross-correlated model is the preferred specification, and the earlier results for the factor intensity variables remain intact. The results for PACE are similar as well. For the Netherlands, the counterintuitive positive effect shows up again, now in both PI and NPI industries. For Germany, the effect on PI industries is negative, but the effect in NPI industries is significant and positive. In the US, the greatest negative effect occurs for PI industries, and although the effect in NPI industries is positive, it is not significantly different from zero. A slightly different specification, containing PACEPI in addition to PACE, would show whether the estimate of PACE for PI industries is larger in absolute value than the estimate of PACE for all industries, as we would expect. The results ${ }^{13}$ indicate that this is only the case for Germany.

In Table 6, we show the results for a somewhat stricter categorization of industries. In effect, we separate ISIC 37, the Basic Metal industry, which is the only industry that is both PI and NRB, from all other industries. The theoretical expectation is that the effect of stringency of environmental policy on net exports will be the most pronounced in the PI/NRB sector.

The results (see Table 6) invariably show that the heteroskedastic cross-correlated model is the preferred alternative, and the results for the factor intensity variables are virtually identical. For the Netherlands, the PACE results are similar to our earlier findings. They are persistently significant and

\footnotetext{
${ }^{13}$ Results are not shown here, but are available upon request.
} 
positive, and do not vary over the different industry categorizations. With respect to Germany, both coefficient estimates are now negative, as expected, but neither is significantly different from zero. For the US, we once again find the most negative effect on the sector that is most vulnerable in terms of environmental regulation. However, the effect on all other industries is now positive and significant.

In sum, there are variations in the effect of PACE both across countries and across industries following their pollution intensity and degree of being resource-based. For Germany and the US, there is some evidence of a negative association between PACE and net exports. This evidence is stronger for the US than for Germany. We also see signs that the effect is stronger for pollution intensive and non-resource-based industries. For the Netherlands, however, there is no evidence whatsoever for the hypothesized negative link. We also observe that the magnitude of the effect of environmental policy on net exports is generally greater for countries where the environmental regulation is stricter.

However, there is no unequivocal support for the theoretically expected negative correlation between strictness of environmental regulation and international competitiveness of industry, not even for the intensive polluters and 'footloose' industries, although our results for the US indicate that the situation comes very close to the hypothesized effect.

These conclusions are of course dependent on our (limited) ability to clearly distinguish pollutionintensive and non-resource-based industries. Moreover, following Copeland and Taylor's (2003) observation that relative factor-abundance conditions and stringency of regulation interact in a variety of ways, resulting in heterogeneous effects across industries, we investigate sectoral variation per se in the next subsection.

\subsection{Sectoral variation per se}

We explicitly address whether or not there is sectoral variation, and whether this variation can be explained by concurrent variations in pollution, natural resource, and factor intensities. Hence, we allow for sectoral variation in the PACE coefficient of equation (3), and then heuristically interpret the different characteristics of a sector in terms of the relative vulnerability of a sector vis-à-vis the strictness of environmental policy. 
$<$ Table 7 about here $>$

The estimation results, presented in Table 7, once again show preference for the heteroskedastic cross-correlated model, but now the results for the factor-intensity variables are slightly different from those reported above. The most significant changes are the sign reversals of man-made capital for Germany, and unskilled labor for the US.

With respect to the industry-by-industry PACE effects clear sectoral variation is apparent across sectors as well as countries. For Germany, ISIC 32-34 (textiles, wood, and paper industries) show declining net exports resulting from environmental regulation. For the Netherlands, ISIC 32, although not statistically significant, and 33 show similar effects. ISIC 38 (metal products), however, shows the greatest environmental policy impact. Similarly, in the US, ISIC 32 and 33, although the latter is not significant, show a negative correlation, as well as ISIC 37 (basic metal products) and 38 although the latter is again not significantly different from zero.

Can we heuristically interpret these findings in terms of pollution, resource base, and factor intensities? Going back to the results allowing for variation in PI and NRB industries (see Tables 5 and 6) shows that the current results are not at odds with those obtained earlier. Sectors 34 and 37 are again susceptible to environmental regulation, although the current results reveal that this conclusion holds specifically for ISIC 34 in Germany, and ISIC 37 in the US. We now also find that ISIC 32, 33, and 38 (except for Germany) are prone to be affected by environmental policy. Hence, while pollution and natural-resource intensity can be seen as necessary criteria for the categorization of heterogeneity of industries in view of environmental policy-making, they are not sufficient. Arguably, other sectoral characteristics, specifically factor intensity, are most likely relevant as well. For instance, ISIC 32 and 33 are affected by environmental policy, but they are at the same time the most unskilled-laborintensive industries (see also Figure 3). Consequently, while these industries are most likely not subject to the most stringent environmental regulation, the relative factor abundance condition (i.e., the relative scarcity of unskilled labor) implies that even a moderately stringent regulation evokes a decline in net exports. We take this as plain support for Copeland and Taylor's (2003) view that trade patterns are determined jointly by relative factor abundance and relative stringency of environmental 
regulation. Even more so, because the non-susceptibility of ISIC 31, 35-36, and 39 that we find, can be explained by the high intensity as well as abundance of man-made capital and skilled labor in these sectors in each of the countries considered. Admittedly, the case is less clear-cut for ISIC 38, for which we find rather counterintuitive results. Finally, although the results for ISIC 34 and 37 may seem erratic, we would like to point out that these sectors are relatively intensive in terms of skilled labor and man-made capital. Since the three countries are abundant in these factors, the factor intensity of these industries neutralizes the eroding effect of stringent environmental regulation on export competitiveness.

Summing up, the evidence provided by the estimation results allowing for sectoral variation do not lend support to the existence of an unconditional negative link between stringency and net exports for the manufacturing industry in general. There is apparent variation across industries. Ceteris paribus, pollution intensive industries are more susceptible to stringency of environmental regulation. Moreover, the impact of environmental policy is conditional upon sectoral variation in factor intensity and a country's characteristics in terms of factor abundance. Since the countries considered are relatively scarce in unskilled-labor services, even a moderately stringent environmental regulation is prone to lead to a decline in net exports of those industries that are intensive in the use of unskilledlabor services. Conversely, industries which are sufficiently intensive in skilled labor and man-made capital (the abundant factors in each of the three countries) have a more resilient export performance, even under conditions of strict environmental regulation.

This result sheds new light on the results obtained in the literature so far. As mentioned above, the results have not been very consistent and clear (see also Mulatu, Florax and Withagen 2003, for a quantitative assessment). The cross-country studies, based either on the Heckscher-Ohlin (HO) or the gravity modeling approach, show mixed results. While Diakosavvas (1994) and van Beers and van den Bergh (1997) find evidence of the hypothesized negative link, Tobey (1990), Xu (2000), and Harris, Kònyà and Màtyàs (2002) do not. The cross-commodity studies, which are concerned with the US manufacturing industry, using the $\mathrm{HO}$ model, also show varying results, but on average they find evidence for the proclaimed negative link between compliance costs of environmental regulation and export performance of 'dirty' industries. The novelty of our results is the revelation of the link 
between environmental regulation and trade flows not merely being an issue of pollution intensity (or 'dirtiness' for that matter), but the conditioning of this link to differentials in stringency and relative factor abundance.

\section{Conclusions}

In this paper, we obtain new empirical evidence on the effect of environmental regulation compliance costs on the export performance of the manufacturing industry. We specify empirical models in reference to a recently developed general equilibrium model of trade and pollution (Copeland and Taylor 2003). This theoretical model asserts that trade patterns in dirty goods are determined by the interaction of the stringency of environmental regulation and relative factor abundance. Consequently, concurrent empirical analyses should find heterogeneity across sectors and countries with respect to the impact of stringency of regulation on net exports. The observed heterogeneity should be attributable to stringency differentials, sectoral factor intensity, and country-by-country factor abundance.

We estimate empirical models for a newly developed dataset concerned with nine two-digit ISIC manufacturing industries in Germany, the Netherlands, and the US. The analysis involves a series of cross-commodity regressions of net exports on suggested determinants of commodity trade, and pollution abatement capital expenditures. We pay due attention to variations across sectors and countries, and utilize an econometric technique referred to as the time-series cross-section estimator that fits our data characteristics well.

The empirical results show that the estimated effects of stringency of environmental regulation on export competitiveness differ across the three countries. For the US, we consistently find evidence for the hypothesis that stringency of environmental regulation is a source of comparative disadvantage in dirty industries. For Germany, the evidence of this negative link is born out for pollution-intensive industries. For the Netherlands, however, neither the aggregate analysis, nor the analysis allowing for variation across pollution intensity and footloose industries, shows the hypothesized effect. Only when 
allowing for sectoral variation per se, we find evidence for the negative link in the wood and fabricated metal industries.

We show that sectoral variation in pollution intensity and the extent to which industries are resource-based are necessary but not sufficient criteria to explain the industry-by-industry and country-by-country variation in the observed effects of environmental policy on international trade. The observed empirical regularities are, however, consistent with an interpretation that does not only account for stringency differentials in environmental regulation and the dirtiness of different industries, but also explicitly considers the factor intensity of the different industries and the relative factor abundance of countries. For a country in which a specific production factor is relatively scarce and at the same time an industry intensively uses this factor even a modestly stringent environmental regulation will evoke a decline in net exports. This situation occurs for the textiles, wood, and fabricated metal industries in all three countries (except for the latter in Germany). Conversely, industries that are intensive in production factors that are abundant in the countries considered show resilient export performances, even though environmental regulation is relatively strict. We show that this situation prevails in, for instance, the food, chemical, and non-metallic mineral industries in the three countries considered.

Given the lack of robustness of research results in this area, and simultaneously the importance attached to environmental policy-making in the context of international trade, further empirical research is necessary. We recommend such research be focused on the triad of environmental regulation, factor intensity of industries, and relative factor abundance of countries, rather than the consideration of environmental regulation in isolation.

\section{Appendix: Data sources}

Detailed data sources are as follows:

- pollution abatement cost, Bouman (1998)

- GDP deflator, OECD (Organization for Economic Co-operation and Development), 199 OECD main economic indicators (1980-1997), OECD, Paris

- exchange rate, OECD, Purchasing-power-parity, http://www.oecd.org/

- US GDP deflator, US Bureau of Economic Analysis, http://www.bea.doc.gov/

- $\quad$ value added, capital, labor, import and export, and $R \& D$ expenditures, The OECD STANDATABASE for industrial analysis (1974-1993, 1975-1994, 1976-1995, and 1978-1992), R\&D expenditures in industry, 1977-1998 (OECD 2000 edition), 1974-1995 (OECD 1997 
edition), Foreign trade by commodities (OECD 1989-1996, vol. 3), Industrial structure statistics core data (1974-1993, 1975-1994, 1976-1995, and 1978-1992), OECD, Paris.

Bouman (1998) gives extensive details about pollution abatement and control capital expenditures (PACE). Investments directed at protection of workers' health are excluded. The definitions are slightly different for the three countries considered:

- Germany: any new investment directed at protection of environmental damage arising from production processes and at producing environmentally benign products,

- the Netherlands: any investment aimed at the reduction of emissions that arise from production processes and end up outside the premises of the firm, and

- US: any investment aimed at reducing emissions of pollutants (except soil pollutants) arising from production activities.

Table A1 provides the classification of industries with respect to pollution intensity (Low and Yeats 1992), resource-base (UNIDO 1982), and industry classifications (Industrial Statistics Yearbook, 1995, Volume ii, Commodity production statistics, United Nations).

$<$ Table A1 about here $>$

\section{Acknowledgements}

This research is partly funded by the Netherlands Organisation for Scientific Research (NWO) in the Environment and Economy Program. We would like to thank Jeroen van den Bergh, Hendrik Folmer, Shelby Gerking, Michael Rauscher, and Aart de Zeeuw for comments and suggestions on earlier versions of this paper. The usual disclaimer applies.

\section{References}

Anderson, J. (1988). Comment on "cross-section estimation". In R. Feenstra (ed.), Empirical Methods for International Trade (pp. 83-87). Cambridge MA: MIT Press.

Antweiler, W., Copeland, B., and Taylor, S. (2001). Is free trade good for the environment? American Economic Review, 91, 877-907.

Beers, C. v., and Bergh, J. van den (1997). An Empirical Multi-Country Analysis of the Impact of Environmental Regulation on Foreign Trade Flows. Kyklos, 50, 29-46.

Bouman, M. (1998). Environmental Costs and Capital Flight. PhD thesis, Tinbergen Institute Research Series, University of Amsterdam, Amsterdam.

Branson, W., and Monoyios, N. (1977). Factor inputs in U.S. trade. Journal of International Economics, 7, 111-131.

Chiang, A. (1984). Fundamental Methods of Mathematical Economics (third ed.). Singapore: McGraw-Hill.

Copeland, B., and Taylor, S. (1994). North-South trade and the environment. Quarterly Journal of Economics, 109, 755-787.

Copeland, B., and Taylor, S. (1995). Trade and transboundary pollution. American Economic Review, 85, 716-737.

Copeland, B., and Taylor, S. (2003). International Trade and the Environment: Theory and Evidence. Princeton: Princeton University Press.

Deardorff, A. (1984). Testing trade theories and predicting trade flows. In R. Jones and P. Kenen (eds.), Handbook of International Economics (Vol. 1, pp. 468-517). Amsterdam: North-Holland.

Diakosavvas, D. (1994). The impact of environmental policies on agricultural trade. Journal of International Development, 6, 207-218.

Ederington, J., and Minier, J. (2003). Is environmental policy a secondary trade barrier? Canadian Journal of Economics, 36, 137-154. 
Greene, W. (2000). Econometric Analysis (fourth ed.). Upper Saddle River NJ: Prentice Hall International.

Griliches, Z. (1970). Notes on the role of education in production functions and growth. In W. Hansen (ed.), Education, Income, and Human Capital (pp. 71-115). USA: National Bureau of Economic Research, Inc.

Grossman, G., and Krueger, A. (1993). Environmental impacts of a North American free trade agreement. In P. Garber (ed.), The U.S.-Mexican Free Trade Agreement (pp. 13-56). Cambridge MA: MIT Press.

Harkness, J. (1981). Cross-section test of the Heckscher-Ohlin Theorem: Reply. American Economic Review, 71, 1044-1048.

Harkness, J. (1983). The factors-proportions model with many nations, goods and factors: theory and evidence. The Review of Economics and Statistics, 65, 298-305.

Harris, M., Kònyà, L., and Màtyàs, L. (2002). Modeling the impact of environmental regulation on bilateral trade flows: OECD, 1990-1996. The World Economy, 25, 387-405.

Hsiao, C. (1986). Analysis of Panel Data. New York: Cambridge University Press.

Jaffe, A., Peterson, S., Portney, P., and Stavins, R. (1995). Environmental regulation and the competitiveness of US manufacturing: what does the evidence tell us? Journal Economic Literature, 33, 132-163.

Jeppesen, T. (2002). Environmental Regulation in a Federal Framework: Framing Environmental Policy in the European Union. Cheltenham; Northampton: Edward Elgar.

Kalt, J. (1988). The impact of domestic environmental regulatory policies on U.S. international competitiveness. In M. Spence and H. Hazard (eds.), International competitiveness (pp. 221-

Leamer, E. (1988). Cross-section estimation of the effects of trade barriers. In R. Feenstra (ed.), Empirical Methods for International Trade (pp. 51-82). Cambridge MA: MIT press.

Levinson, A., and Taylor, S. (2001). Trade and the Environment. Unmasking the Pollution Haven Effect. Unpublished manuscript, U.S. National Science Foundation.

Low, P., and Yeats, A. (1992). Do 'dirty' industries migrate? In P. Low (ed.), International Trade and the Environment. Washington DC: World Bank.

Mulatu, A. (2004). Relative Stringency of Environmental Regulation and International Competitiveness. Ph.D. thesis, Tinbergen Institute Research Series, Vrije Universiteit Amsterdam.

Mulatu, A., Florax, R., and Withagen, C. (2003). Environmental regulation and competitiveness: an exploratory meta-analysis. In C. Boehringer and A. Loeschel (eds.), Empirical Modeling of the Economy and the Environment (ZEW Economic Studies, Vol. 20, pp. 23-54). Heidelberg: Physica Verlag.

Osang, T., and Nandy, A. (2000). Impact of U.S. Environmental Regulation on the Competitiveness of Manufacturing Industries. Working paper, Southern Methodist University; Public Service Electric and Gas, Newark.

Pethig, R. (1976). Pollution, welfare, and environmental policy in the theory of comparative advantage. Journal of Environmental Economics a nd Management, 2, 160-169.

Siebert, H. (1974). Environmental protection and international specialization. Weltwirtschaftliches Archiv, 110, 494-508.

Siebert, H. (1987). Environmental quality and the gains from trade. Kyklos, 30, 657-673.

Stern, R., and Maskus, K. (1981). Determinants of the structure of U.S. foreign trade, 1958-76. Journal of International Economics, 11, 207-224.

Tobey, J. (1990). The impact of domestic environmental policy on international trade: an empirical test. Kyklos, 43, 191-209.

$\mathrm{Xu}, \mathrm{X}$. (2000). International trade and environmental regulation: time series evidence and crosssection test. Journal of Environmental, Agricultural and Resource Economics , 17, 233-257. 


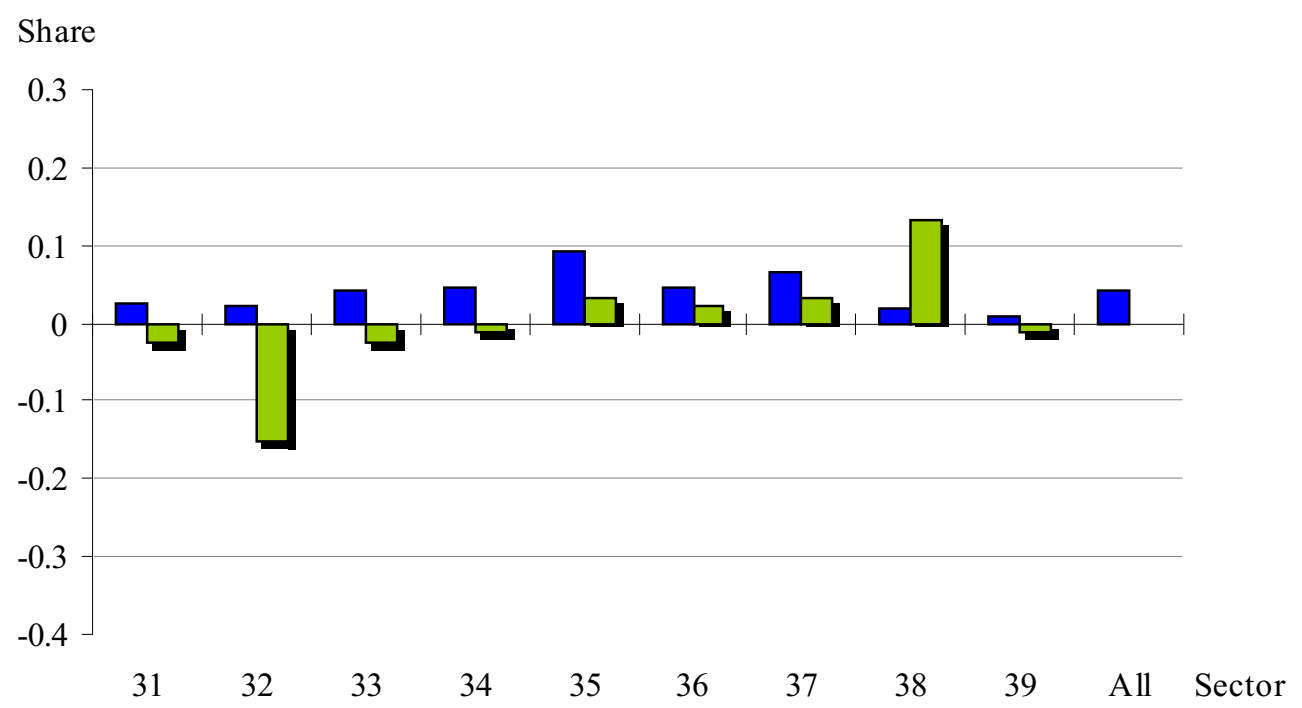

Share

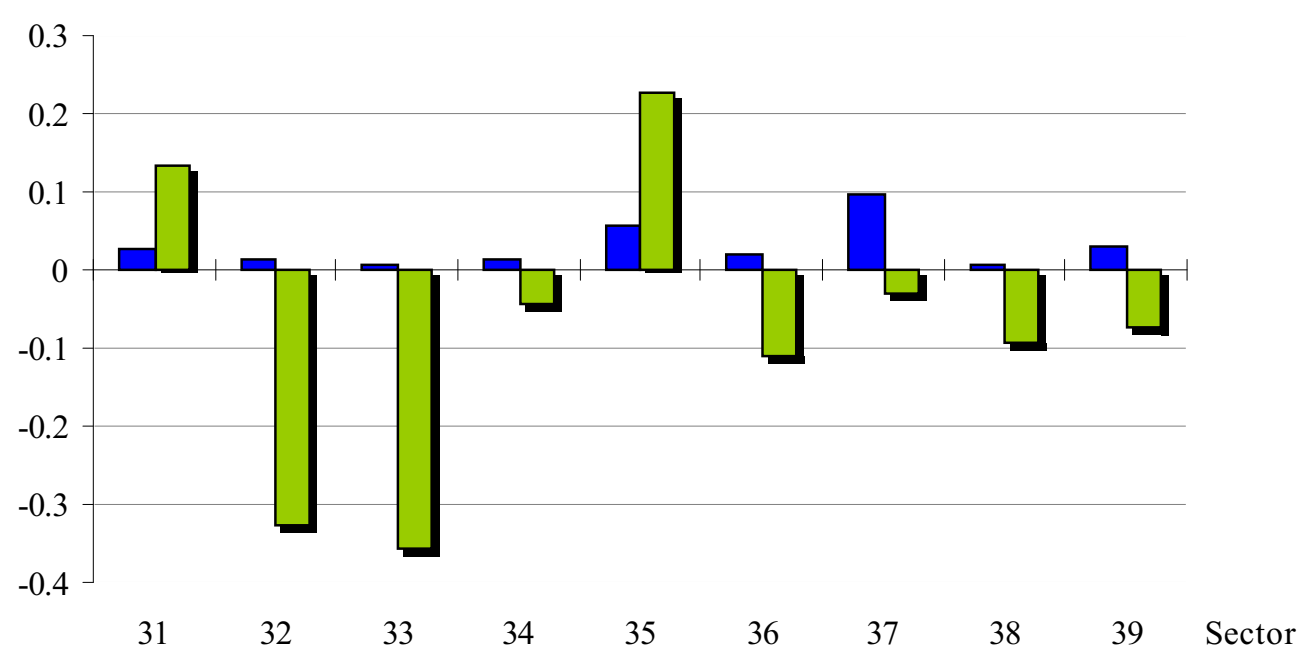

Share

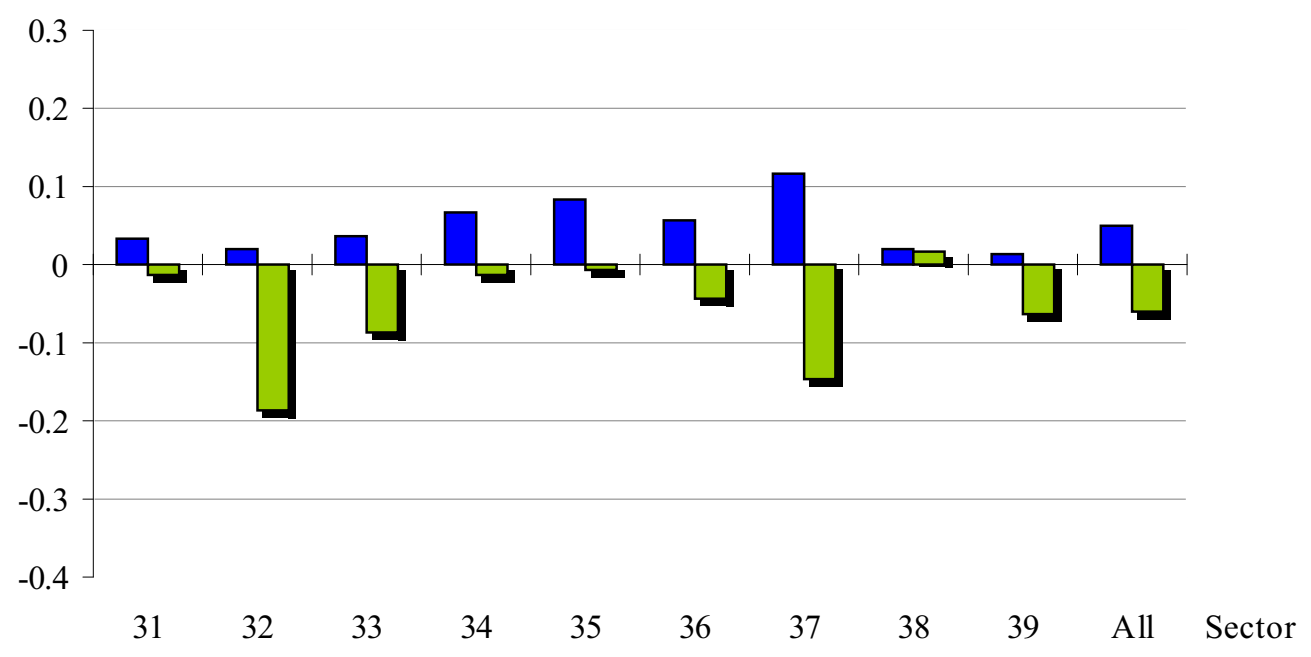

Figure 1: PACE share of capital formation (blue) and net export share of production (green) for different sectors in Germany (top), the Netherlands (middle) and the US (bottom), 1971-1992. 

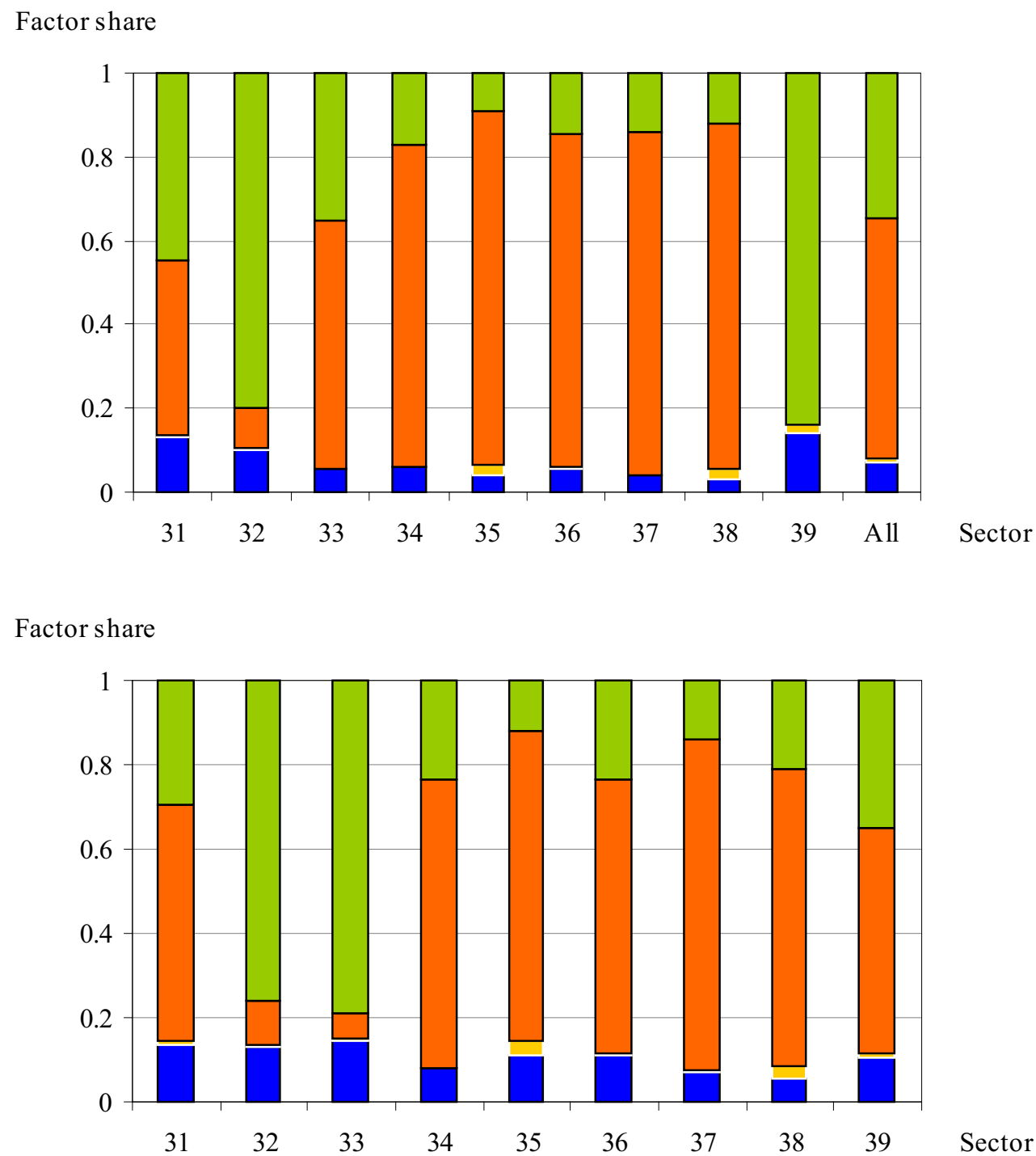

Factor share

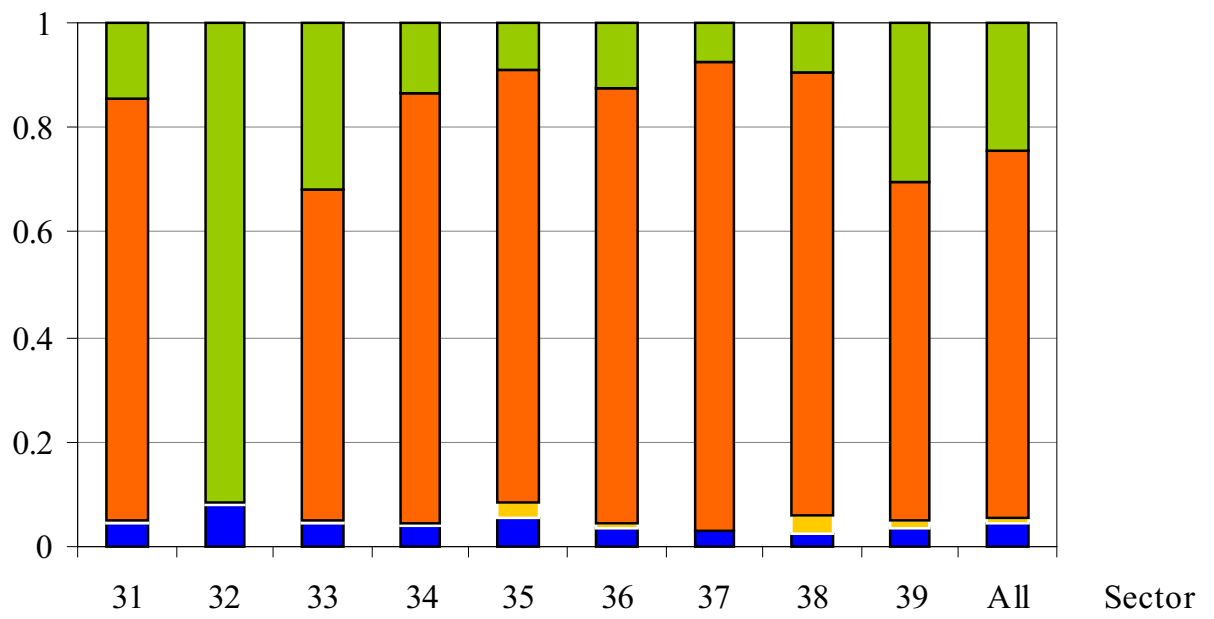

Figure 2: Factor shares of man-made capital (blue), R\&D (yellow), skilled labor (orange), and unskilled labor (green), for different sectors in Germany (top), the Netherlands (middle) and the US (bottom), 19711992. 
Table 1: Two-digit ISIC classification of industries, including pollution intensity and resource basedness ${ }^{\mathrm{a}}$

\begin{tabular}{|c|c|c|c|c|c|}
\hline ISIC & Industry & $\mathrm{RB}$ & NRB & PI & NPI \\
\hline 31 & Food, Beverages and Tobacco & $x$ & & & $x$ \\
\hline 32 & Textiles, Apparel and Leather & $x$ & $x$ & & $x$ \\
\hline 33 & Wood products and Furniture & $x$ & & & $x$ \\
\hline 34 & Paper, Paper products and Printing & $x$ & & $x$ & \\
\hline 35 & Chemical products & $x$ & $x$ & $x$ & $x$ \\
\hline 36 & Non-metallic mineral products & & $x$ & & $x$ \\
\hline 37 & Basic metal products & & $x$ & $x$ & \\
\hline 38 & Fabricated metal products & $x$ & $x$ & $\times$ & $\times$ \\
\hline 39 & Other manufacturing & & $\times$ & & $x$ \\
\hline
\end{tabular}

${ }^{a}$ See the Appendix for details. The meaning of the abbreviations is: resourcebased (RB), non-resource-based (NRB), pollution-intensive good (PI), and non-pollution-intensive good (NPI). 
Table 2: Descriptive statistics for two-digit ISIC industries, 1972-1992

\begin{tabular}{|c|c|c|c|}
\hline \multirow[t]{2}{*}{ Variable } & \multicolumn{3}{|c|}{ Mean and standard deviation (in parentheses) } \\
\hline & Germany & Netherlands & $\mathrm{US}$ \\
\hline \multirow[t]{2}{*}{ Exports $(\times 1,000)$} & 29.949 & 30.161 & 29.006 \\
\hline & $(47.669)$ & $(47.755)$ & $(50.263)$ \\
\hline \multirow[t]{2}{*}{ Imports $(\times 1,000)$} & 21.418 & 21.230 & 36.689 \\
\hline & $(24.541)$ & $(24.711)$ & $(55.147)$ \\
\hline \multirow[t]{2}{*}{ Value of production $(\times 1,000)$} & 168.751 & 29.888 & 280.888 \\
\hline & $(202.891)$ & $(28.455)$ & $(287.829)$ \\
\hline \multirow[t]{2}{*}{ Net exports ${ }^{b}$} & 0.0002 & -0.0764 & -0.0604 \\
\hline & $(0.0761)$ & $(0.1961)$ & $(0.0851)$ \\
\hline \multirow[t]{2}{*}{ Pollution abatement capital expenditure $(\times 1,000)$} & 0.193 & 0.031 & 0.676 \\
\hline & $(0.246)$ & $(0.052)$ & $(0.817)$ \\
\hline \multirow[t]{2}{*}{ New gross fixed capital formation $(\times 1,000)$} & 4.704 & 0.989 & 13.839 \\
\hline & $(5.841)$ & $(0.893)$ & $(15.037)$ \\
\hline \multirow[t]{2}{*}{ Pollution abatement capital expenditure } & 0.04 & 0.03 & 0.05 \\
\hline & $(0.03)$ & $(0.04)$ & $(0.04)$ \\
\hline \multirow[t]{2}{*}{ Research and development expenditure $(\times 1,000)$} & 2.197 & 0.286 & 10.077 \\
\hline & $(4.572)$ & $(0.475)$ & $(22.408)$ \\
\hline \multirow[t]{2}{*}{ Skilled-labor services $(\times 1,000)$} & 92.725 & 8.122 & 329.682 \\
\hline & $(154.038)$ & $(9.038)$ & $(484.524)$ \\
\hline \multirow[t]{2}{*}{ Unskilled labor services $(\times 1,000)$} & 16.865 & 2.616 & 49.354 \\
\hline & $(20.975)$ & $(2.363)$ & $(52.030)$ \\
\hline
\end{tabular}

${ }^{\mathrm{a}}$ Data availability across countries varies slightly according to time periods. For the US, data are available for 1973-1991, for Germany from 1975-1992, and for the Netherlands from 1972-1992. For every country, there are some missing observations for specific variables. Data prior to 1977 are not employed because data for research and development are lacking. The database contains 9 twodigit ISIC industries, but for the Netherlands, observations for ISIC 39 are missing. Since one of theeconometric techniques we use requires a balanced panel, the years 1987 and 1988 are dropped for the Netherlands because of missing PACE data for ISIC 35 and ISIC 36. Similarly, the year 1987 is dropped for the US data because PACE data are missing. All monetary values are in thousands of 1996 US dollars.

${ }^{\mathrm{b}}$ Scaled by total value of production of the same industry.

${ }^{c}$ Scaled by total fixed capital formation of the same industry. 
Table 3: Cross-commodity regressions of net exports as a share of the value of production, for nine different sectors in three different countries, $1977-1992^{\text {a }}$

\begin{tabular}{|c|c|c|c|c|c|c|c|c|c|}
\hline \multirow[t]{3}{*}{ Variable } & \multicolumn{9}{|c|}{ Model } \\
\hline & \multicolumn{3}{|c|}{ Pooled cross-section } & \multicolumn{3}{|c|}{ Fixed effects ${ }^{\mathrm{b}}$} & \multicolumn{3}{|c|}{ Random effects } \\
\hline & Germany & Netherlands & US & Germany & Netherlands & US & Germany & Netherlands & US \\
\hline Constant & $\begin{array}{c}-0.025^{*} \\
(0.009)\end{array}$ & $\begin{array}{c}-0.292^{* *} \\
(0.019)\end{array}$ & $\begin{array}{c}-0.020 \\
(0.014)\end{array}$ & & & & $\begin{array}{c}-0.010 \\
(0.019)\end{array}$ & $\begin{array}{c}-0.075 \\
(0.040)\end{array}$ & $\begin{array}{c}-0.083^{* *} \\
(0.013)\end{array}$ \\
\hline Man-made capital & $\begin{array}{l}1.275^{* *} \\
(0.343)\end{array}$ & $\begin{array}{l}19.710^{* *} \\
(1.821)\end{array}$ & $\begin{array}{c}0.493^{* *} \\
(0.097)\end{array}$ & $\begin{array}{c}-0.045 \\
(0.388)\end{array}$ & $\begin{array}{c}2.392 \\
(1.948)\end{array}$ & $\begin{array}{c}0.203 \\
(0.122)\end{array}$ & $\begin{array}{c}-0.446 \\
(0.338)\end{array}$ & $\begin{array}{c}1.546 \\
(1.747)\end{array}$ & $\begin{array}{c}0.321^{* *} \\
(0.087)\end{array}$ \\
\hline Skilled labor & $\begin{array}{c}0.169^{* *} \\
(0.015)\end{array}$ & $\begin{array}{l}2.063^{* *} \\
(0.454)\end{array}$ & $\begin{array}{c}0.033^{* *} \\
(0.006)\end{array}$ & $\begin{array}{c}-0.016 \\
(0.039)\end{array}$ & $\begin{array}{c}0.236 \\
(0.317)\end{array}$ & $\begin{array}{c}-0.017 \\
(0.009)\end{array}$ & $\begin{array}{c}0.095^{* *} \\
(0.023)\end{array}$ & $\begin{array}{c}0.279 \\
(0.310)\end{array}$ & $\begin{array}{c}0.017^{* *} \\
(0.005)\end{array}$ \\
\hline Unskilled labor & $\begin{array}{c}-0.649^{* *} \\
(0.094)\end{array}$ & $\begin{array}{c}-2.488^{*} \\
(0.948)\end{array}$ & $\begin{array}{c}-0.254^{* *} \\
(0.041)\end{array}$ & $\begin{array}{c}-0.245 \\
(0.191)\end{array}$ & $\begin{array}{c}-5.014^{*} \\
(1.844)\end{array}$ & $\begin{array}{c}0.077 \\
(0.087)\end{array}$ & $\begin{array}{c}-0.203 \\
(0.161)\end{array}$ & $\begin{array}{c}-0.971 \\
(1.190)\end{array}$ & $\begin{array}{c}-0.046 \\
(0.039)\end{array}$ \\
\hline $\mathrm{R} \& \mathrm{D}$ & $\begin{array}{c}-3.461^{* *} \\
(0.489)\end{array}$ & $\begin{array}{c}-46.513^{* *} \\
(6.005)\end{array}$ & $\begin{array}{c}-0.422^{* *} \\
(0.105)\end{array}$ & $\begin{array}{c}0.490 \\
(0.707)\end{array}$ & $\begin{array}{r}-10.420 \\
(4.377)\end{array}$ & $\begin{array}{c}-0.416^{*} \\
(0.081)\end{array}$ & $\begin{array}{c}-1.142 \\
(0.520)\end{array}$ & $\begin{array}{c}-6.887 \\
(3.918)\end{array}$ & $\begin{array}{c}-0.417^{* *} \\
(0.074)\end{array}$ \\
\hline PACE & $\begin{array}{c}-0.260 \\
(0.145)\end{array}$ & $\begin{array}{l}1.222^{* *} \\
(0.240)\end{array}$ & $\begin{array}{c}-1.320^{* *} \\
(0.206)\end{array}$ & $\begin{array}{c}-0.045 \\
(0.111)\end{array}$ & $\begin{array}{c}0.205 \\
(0.118)\end{array}$ & $\begin{array}{c}0.214 \\
(0.184)\end{array}$ & $\begin{array}{c}-0.006 \\
(0.110)\end{array}$ & $\begin{array}{c}0.223 \\
(0.117)\end{array}$ & $\begin{array}{c}-0.322^{*} \\
(0.153)\end{array}$ \\
\hline Number of observations & 144 & 124 & 126 & 144 & 124 & 126 & 144 & 124 & 126 \\
\hline Number of cross-section units & 9 & 8 & 9 & 9 & 8 & 9 & 9 & 8 & 9 \\
\hline Number of time periods & 16 & 14 & 14 & 16 & 14 & 14 & 16 & 14 & 14 \\
\hline Degrees of freedom & 137 & 134 & 135 & 128 & 126 & 126 & 136 & 133 & 134 \\
\hline Adj. $R^{2}$ & 0.69 & 0.73 & 0.44 & 0.89 & 0.96 & $0.81_{* *}$ & & & \\
\hline$F$ & & & & $89.85^{* *}$ & $264.95^{* *}$ & $42.48^{* *}$ & & & \\
\hline $\mathrm{LR}^{\mathrm{c}}$ & & & & $156.41^{* *}$ & $253.65^{* *}$ & $1402.00^{* *}$ & & & \\
\hline Hausman test ${ }^{\mathrm{d}}$ & & & & & & & $15.80^{* *}$ & $39.35 * *$ & $92.54^{* *}$ \\
\hline $\mathrm{LM}^{\mathrm{e}}$ & $70.00^{* *}$ & $39.18^{* *}$ & $56.00^{* *}$ & & & & & & \\
\hline
\end{tabular}

${ }^{a}$ Standard errors are given in parentheses, and * and ** indicate significance at the 5 and $1 \%$ level, respectively.

${ }^{\mathrm{b}}$ The estimated coefficients of the group-specific effects are omitted. They are rather similar across data sets, and only few are statistically different from zero.

${ }^{\mathrm{c}}$ The LR statistic refers to a test of the null hypothesis of the pooled cross-section model against the fixed effects model. The statistic has a $\chi^{2}$ distribution with ( $\left.n-1\right)$ degrees of freedom, where $n$ is the number of cross-section units. Note that the estimates of the fixed effects model include coefficients for group-specific effects.

${ }^{\mathrm{d}}$ The Hausman test is a test of the null hypothesis of the random effects model against the fixed effects model. The statistic has a $\chi^{2}$ distribution with 5 degrees of freedom.

${ }^{\mathrm{e}}$ The LM statistic refers to a test of the null hypothesis of homoskedasticity. The statistic has a $\chi^{2}$ distribution with $(n-1)$ degrees of freedom, where $n$ is the number of

cross-section units. 
Table 4: Cross-commodity regressions of net exports as a share of the value of production, for nine different sectors in three different countries, 1977-1992 ${ }^{\mathrm{a}}$

\begin{tabular}{|c|c|c|c|c|c|c|}
\hline \multirow[t]{3}{*}{ Variable } & \multicolumn{6}{|c|}{ Model } \\
\hline & \multicolumn{3}{|c|}{ Heteroskedasticity } & \multicolumn{3}{|c|}{ Heteroskedasticity and cross-correlation } \\
\hline & Germany & Netherlands & US & Germany & Netherlands & US \\
\hline \multirow[t]{2}{*}{ Constant } & $0.021^{* *}$ & $-0.271^{* *}$ & -0.017 & $-0.021^{* * *}$ & $-0.256^{* *}$ & 0.016 \\
\hline & $(0.007)$ & $(0.018)$ & $(0.011)$ & $(0.003)$ & $(0.007)$ & $(0.009)$ \\
\hline \multirow[t]{2}{*}{ Man-made capital } & -0.285 & $20.870^{* *}$ & $0.390^{* *}$ & $0.213^{*}$ & $19.490^{* *}$ & $0.302^{* *}$ \\
\hline & $(0.254)$ & $(1.774)$ & $(0.083)$ & $(0.077)$ & $(0.881)$ & $(0.039)$ \\
\hline \multirow[t]{2}{*}{ Skilled labor } & $0.117^{* *}$ & $1.734^{* *}$ & $0.024^{* *}$ & $0.114^{*}$ & $1.176^{*}$ & $0.020^{* *}$ \\
\hline & $(0.012)$ & $(0.414)$ & $(0.007$ & $(0.003)$ & $(0.256)$ & $(0.003)$ \\
\hline \multirow[t]{2}{*}{ Unskilled labor } & $-0.294^{* *}$ & $-2.255^{*}$ & $-0.168^{* *}$ & $-0.286^{* *}$ & $-1.398^{*}$ & $-0.115^{* *}$ \\
\hline & $(0.069)$ & $(0.270)$ & $(0.042)$ & $(0.010)$ & $(0.105)$ & $(0.016)$ \\
\hline \multirow[t]{2}{*}{$\mathrm{R} \& \mathrm{D}$} & $-2.104^{* *}$ & $-45.140^{* *}$ & $-0.387^{* *}$ & $-1.931^{* *}$ & $-399.00^{* *}$ & $-0.353^{* *}$ \\
\hline & $(0.365)$ & $(6.171)$ & $(0.083)$ & $(0.026)$ & $(2.300)$ & $(0.030)$ \\
\hline \multirow[t]{2}{*}{ PACE } & -0.068 & $1.133^{* *}$ & $-1.005^{* *}$ & -0.257 & $0.956^{* *}$ & $-0.671^{* *}$ \\
\hline & $(0.080)$ & $(0.210)$ & $(0.188)$ & $(0.026)$ & $(0.105)$ & $(0.090)$ \\
\hline Log-likelihood & 322.52 & 112.66 & 226.66 & 412.53 & 1760.00 & 312.53 \\
\hline No. of observations & 144 & 112 & 126 & 144 & 112 & 126 \\
\hline No. of cross-section units & 9 & 8 & 9 & 9 & 8 & 9 \\
\hline No. of time periods & 16 & 14 & 14 & 16 & 14 & 14 \\
\hline No. of estimated parameters ${ }^{b}$ & 15 & 14 & 15 & 51 & 42 & 51 \\
\hline 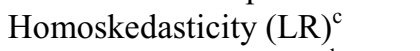 & $132.98^{* *}$ & $182.00^{*}$ & $89.06^{* *}$ & & & \\
\hline Cross-correlation (LR) ${ }^{\mathrm{d}}$ & & & & $180.02^{* *}$ & $129.88^{* *}$ & $171.74^{* *}$ \\
\hline
\end{tabular}

\footnotetext{
${ }^{a}$ Standard errors are given in parentheses, and * and ** indicate significance at the 5 and $1 \%$ level, respectively.

${ }^{\mathrm{b}}$ The number of estimated parameters corresponds to the loss of degrees of freedom. The total loss corresponds to the number of coefficient estimates plus the estimated parameters of the variance-covariance structure.

${ }^{\mathrm{c}}$ The LR statistic refers to a test of the null-hypothesis of homoskedasticity, and it has a $\chi^{2}$ distribution with $(n-1)$ degrees of freedom, where $n$ is the number of cross-section units.

${ }^{\mathrm{d}}$ The LR statistic refers to a test of the null-hypothesis of no cross-correlation, and the test has a $\chi^{2}$ distribution with $n(n-1) / 2$ degrees of freedom, where $n$ is the number of cross-section units. To test the hypothesis of both homoskedasticity and no cross-correlated disturbances, the test statistic is the sum of the LR statistic of homoskedasticity and the LR statistic of no cross-correlation. The combined test has a $\chi^{2}$ distribution with $n(n-1) / 2$ degrees of freedom, where $n$ is the number of cross-section units. The joint test is rejected in all cases.
} 
Table 5: Cross-commodity regressions of net exports as a share of the value of production with a distinction between pollution-intensive (PI) and non-pollution-intensive (NPI) sectors, for nine different sectors in three different countries, 1977-1992 ${ }^{\mathrm{a}}$

\begin{tabular}{|c|c|c|c|c|c|c|}
\hline \multirow[t]{3}{*}{ Variable } & \multicolumn{6}{|c|}{ Model } \\
\hline & \multicolumn{3}{|c|}{ Heteroskedasticity } & \multicolumn{3}{|c|}{ Heteroskedasticity and cross-correlation } \\
\hline & Germany & Netherlands & US & Germany & Netherlands & US \\
\hline \multirow[t]{2}{*}{ Constant } & $-0.028^{* *}$ & $-0.272^{* *}$ & $-0.060^{* *}$ & $-0.028^{* *}$ & $-0.256^{* * *}$ & $-0.063^{* *}$ \\
\hline & $(0.008)$ & $(0.018)$ & $(0.012)$ & $(0.003)$ & $(0.007)$ & $(0.003)$ \\
\hline \multirow[t]{2}{*}{ Man-made capital } & 0.229 & $20.810^{* *}$ & $0.225^{* *}$ & $0.197^{* *}$ & $19.449^{* *}$ & $0.188^{* *}$ \\
\hline & $(0.254)$ & $(2.159)$ & $(0.079)$ & $(0.069)$ & $(0.954)$ & $(0.039)$ \\
\hline \multirow[t]{2}{*}{ Skilled labor } & $0.127^{* *}$ & $1.745^{* *}$ & $0.033^{* *}$ & $0.119^{* *}$ & $1.182^{* *}$ & $0.031^{* *}$ \\
\hline & $(0.013)$ & $(0.444)$ & $(0.006)$ & $(0.004)$ & $(0.256)$ & $(0.002)$ \\
\hline \multirow[t]{2}{*}{ Unskilled labor } & $-0.228^{* *}$ & $-2.253^{*}$ & $-0.108^{* *}$ & $-0.209^{* *}$ & $-1.398^{*}$ & $-0.080^{* *}$ \\
\hline & $(0.075)$ & $(0.931)$ & $(0.038)$ & $(0.021)$ & $(0.586)$ & $(0.012)$ \\
\hline \multirow[t]{2}{*}{$\mathrm{R} \& \mathrm{D}$} & $-2.702^{* *}$ & -45.270 & $-0.609^{* *}$ & $-2.482^{* *}$ & $-38.047^{* *}$ & $-0.582^{* *}$ \\
\hline & $(0.445)$ & $(6.435)$ & $(0.089)$ & $(0.144)$ & $(3.015)$ & $(0.034)$ \\
\hline \multirow[t]{2}{*}{ PACE-NPI ${ }^{\mathrm{b}}$} & 0.120 & $1.162^{*}$ & -0.099 & $0.141^{* *}$ & $0.970^{* *}$ & 0.047 \\
\hline & $(0.111)$ & $(0.512)$ & $(0.214)$ & $(0.028)$ & $(0.169)$ & $(0.063)$ \\
\hline \multirow[t]{2}{*}{ PACE-PI ${ }^{b}$} & -0.136 & 1.130 & $-1.181^{* *}$ & $-0.080^{*}$ & 0.953 & $-0.978^{* *}$ \\
\hline & $(0.084)$ & $(0.216)$ & $(0.185)$ & $(0.031)$ & $(0.119)$ & $(0.080)$ \\
\hline Log-likelihood & 3241.00 & 112.65 & 2200.00 & 411.67 & 1758.00 & 308.39 \\
\hline No. of observations & 144 & 112 & 126 & 144 & 112 & 126 \\
\hline No. of cross-section units & 9 & 8 & 9 & 9 & 8 & 9 \\
\hline No. of time periods & 16 & 14 & 14 & 16 & 14 & 14 \\
\hline No. of estimated parameters & 16 & 15 & 16 & 52 & 43 & 52 \\
\hline Homoskedasticity (LR) & $141.24^{* *}$ & $180.00^{*}$ & 74.87 & & & \\
\hline Cross-correlation (LR) & & & & $168.53^{* *}$ & $112.65^{* *}$ & $162.78^{* *}$ \\
\hline
\end{tabular}

${ }^{a}$ See the notes to Table 4.

${ }^{\mathrm{b}}$ Effectively, PACE-PI concerns ISIC 34 and 37, and PACE-NPI all other industries. 
Table 6: Cross-commodity regressions of net exports as a share of the value of production with a distinction between pollution-intensive non-resource-based (PI/NRB) and non-pollution-intensive resource-based (NPI/RB) sectors, for nine different sectors in three different countries, 1977-1992 ${ }^{\mathrm{a}}$

\begin{tabular}{|c|c|c|c|c|c|c|}
\hline \multirow[t]{3}{*}{ Variable } & \multicolumn{6}{|c|}{ Model } \\
\hline & \multicolumn{3}{|c|}{ Heteroskedasticity } & \multicolumn{3}{|c|}{ Heteroskedasticity and cross-correlation } \\
\hline & Germany & Netherlands & US & Germany & Netherlands & US \\
\hline \multirow[t]{2}{*}{ Constant } & $-0.019^{*}$ & $-0.271^{* *}$ & $-0.058^{*}$ & $-0.019^{* * *}$ & $-0.256^{* *}$ & $-0.054^{* *}$ \\
\hline & $(0.008)$ & $(0.018)$ & $(0.008)$ & $(0.003)$ & $(0.007)$ & $(0.003)$ \\
\hline \multirow[t]{2}{*}{ Man-made capital } & 0.274 & $20.889^{* *}$ & 0.104 & $0.186^{*}$ & $19.496^{* *}$ & $0.076^{* *}$ \\
\hline & $(0.257)$ & $(2.085)$ & $(0.064)$ & $(0.080)$ & $(0.912)$ & $(0.023)$ \\
\hline \multirow[t]{2}{*}{ Skilled labor } & $0.115^{* *}$ & $1.738^{* *}$ & $0.033^{* *}$ & $0.113^{* *}$ & $1.179^{* *}$ & $0.032^{* *}$ \\
\hline & $(0.014)$ & $(0.427)$ & $(0.005)$ & $(0.003)$ & $(0.256)$ & $(0.001)$ \\
\hline \multirow[t]{2}{*}{ Unskilled labor } & $-0.297^{* *}$ & $-2.260^{*}$ & $-0.145^{* *}$ & $-0.279^{* *}$ & $-1.400^{*}$ & $-0.133^{* *}$ \\
\hline & $(0.070)$ & $(0.931)$ & $(0.031)$ & $(0.015)$ & $(0.579)$ & $(0.010)$ \\
\hline \multirow[t]{2}{*}{$\mathrm{R} \& \mathrm{D}$} & $-2.015^{* *}$ & $-45.196^{* *}$ & $-0.417^{* *}$ & $-1.893^{* *}$ & $-38.044^{* *}$ & $-0.402^{* *}$ \\
\hline & $(0.470)$ & $(6.232)$ & $(0.054)$ & $(0.158)$ & $(3.002)$ & $(0.025)$ \\
\hline \multirow[t]{2}{*}{$\mathrm{PACE}-\mathrm{NPI} / \mathrm{RB}^{\mathrm{b}}$} & -0.077 & $1.130^{*}$ & 0.146 & -0.022 & $0.959^{* *}$ & $0.149^{* *}$ \\
\hline & $(0.087)$ & $(0.491)$ & $(0.124)$ & $(0.029)$ & $(0.170)$ & $(0.037)$ \\
\hline \multirow[t]{2}{*}{$\mathrm{PACE}-\mathrm{PI} / \mathrm{NRB}^{\mathrm{b}}$} & -0.047 & 1.132 & $-1.305^{* *}$ & -0.024 & 0.954 & $-1.238^{* *}$ \\
\hline & $(0.122)$ & $(0.215)$ & $(0.185)$ & $(0.037)$ & $(0.120)$ & $(0.097)$ \\
\hline Log-likelihood & 322.93 & 112.64 & 242.85 & 413.15 & 1757.00 & 319.31 \\
\hline No. of observations & 144 & 124 & 126 & 144 & 124 & 126 \\
\hline No. of cross-section units & 9 & 8 & 9 & 9 & 8 & 9 \\
\hline No. of time periods & 16 & 14 & 14 & 16 & 14 & 14 \\
\hline No. of estimated parameters & 16 & 15 & 16 & 52 & 43 & 52 \\
\hline Homoskedasticity (LR) & $132.50^{* *}$ & $178.00^{*}$ & $84.61^{* *}$ & & & \\
\hline Cross-correlation (LR) & & & & $180.43^{* *}$ & $129.86^{* *}$ & $152.92^{* *}$ \\
\hline
\end{tabular}

${ }^{\mathrm{a}}$ See the notes to Table 4.

${ }^{\mathrm{b}}$ Effectively, PACE-PI/NRB concerns ISIC 37, and PACE-NPI/RB all other industries. 
Table 7: Cross-commodity regressions of net exports as a share of the value of production with a sector specific PACE coefficient, for nine different sectors in three different countries, 1977-1992 ${ }^{\mathrm{a}}$

\begin{tabular}{|c|c|c|c|c|c|c|}
\hline \multirow[t]{3}{*}{ Variable } & \multicolumn{6}{|c|}{ Model } \\
\hline & \multicolumn{3}{|c|}{ Heteroskedasticity } & \multicolumn{3}{|c|}{ Heteroskedasticity and cross-correlation } \\
\hline & Germany & Netherlands ${ }^{\mathrm{b}}$ & US & Germany & Netherlands ${ }^{\mathrm{b}}$ & US \\
\hline \multirow[t]{2}{*}{ Constant } & -0.011 & $-0.222^{* *}$ & $-0.112^{* *}$ & $-0.010^{*}$ & $-0.193^{* *}$ & $-0.102^{* *}$ \\
\hline & $(0.007)$ & $(0.020)$ & $(0.010)$ & $(0.004)$ & $(0.010)$ & $(0.005)$ \\
\hline \multirow[t]{2}{*}{ Man-made capital } & -0.494 & $9.901^{* *}$ & 0.168 & $-0.512^{* *}$ & $8.680^{* *}$ & 0.083 \\
\hline & $(0.209)$ & $(3.054)$ & $(0.106)$ & $(0.090)$ & $(1.227)$ & $(0.045)$ \\
\hline \multirow[t]{2}{*}{ Skilled labor } & $0.085^{* *}$ & $2.581^{* *}$ & $0.018^{*}$ & $0.084^{* *}$ & $1.960^{* *}$ & $0.014^{* *}$ \\
\hline & $(0.012)$ & $(0.538)$ & $(0.007)$ & $(0.005)$ & $(0.309)$ & $(0.003)$ \\
\hline \multirow[t]{2}{*}{ Unskilled labor } & -0.134 & $-3.432^{*}$ & 0.035 & $-0.112^{*}$ & $-3.343^{* *}$ & $0.085^{* *}$ \\
\hline & $(0.104)$ & (1.300) & $(0.054)$ & $(0.040)$ & $(0.665)$ & $(0.023)$ \\
\hline \multirow[t]{2}{*}{$\mathrm{R} \& \mathrm{D}$} & $-1.327^{* *}$ & $-34.491^{* *}$ & $-0.475^{* *}$ & $-1.350^{* *}$ & $-25.561^{* *}$ & $-0.447^{* *}$ \\
\hline & $(0.309)$ & $(5.986)$ & $(0.080)$ & $(0.156)$ & $(2.934)$ & $(0.037)$ \\
\hline \multirow[t]{2}{*}{ PACE-ISIC 31} & $0.796^{*}$ & $5.101^{* *}$ & $1.508^{* *}$ & $0.615^{* *}$ & $4.795^{* *}$ & $1.072^{* *}$ \\
\hline & $(0.359)$ & $(1.305)$ & $(0.353)$ & $(0.182)$ & $(0.559)$ & $(0.211)$ \\
\hline \multirow[t]{2}{*}{ PACE-ISIC 32} & $-5.432^{* *}$ & $-1.564^{* *}$ & $-5.420^{* *}$ & $-5.267^{* *}$ & -0.681 & $-6.150^{* *}$ \\
\hline & $(0.495)$ & $(0.889)$ & $(1.920)$ & $(0.306)$ & $(0.614)$ & $(1.284)$ \\
\hline \multirow[t]{2}{*}{ PACE-ISIC 33} & -0.135 & -5.747 & 0.222 & $-0.142^{* *}$ & $-4.284^{*}$ & -0.294 \\
\hline & $(0.097)$ & (3.159) & $(0.352)$ & $(0.045)$ & $(1.901)$ & $(0.216)$ \\
\hline \multirow[t]{2}{*}{ PACE-ISIC 34} & -0.073 & 1.043 & 0.220 & $-0.076^{*}$ & 0.459 & 0.125 \\
\hline & $(0.079)$ & (1.069) & $(0.182)$ & $(0.035)$ & $(0.429)$ & $(0.081)$ \\
\hline \multirow[t]{2}{*}{ PACE-ISIC 35} & $0.354^{* *}$ & 1.467 & 0.423 & $0.354^{* *}$ & $0.904^{* *}$ & $0.484^{* *}$ \\
\hline & $(0.122)$ & $(0.816)$ & $(0.269)$ & $(0.058)$ & $(0.278)$ & $(0.153)$ \\
\hline \multirow[t]{2}{*}{ PACE-ISIC 36} & $0.535^{* *}$ & $1.486^{*}$ & $0.938^{* *}$ & $0.550^{* *}$ & $0.778^{*}$ & $0.752^{* *}$ \\
\hline & $(0.106)$ & $(0.623)$ & $(0.163)$ & $(0.052)$ & $(0.337)$ & $(0.089)$ \\
\hline \multirow[t]{2}{*}{ PACE-ISIC 37} & $0.219^{*}$ & $0.849^{* *}$ & $-0.875^{* *}$ & $0.198^{* *}$ & $0.582^{* *}$ & $-0.773^{* *}$ \\
\hline & $(0.089)$ & $(0.200)$ & $(0.144)$ & $(0.061)$ & $(0.118)$ & $(0.108)$ \\
\hline \multirow[t]{2}{*}{ PACE-ISIC 38} & 4.998 & $-9.919^{*}$ & -1.252 & $5.002^{* *}$ & $-6.710^{* *}$ & -1.679 \\
\hline & $(2.259)$ & (4.409) & $(3.146)$ & $(1.152)$ & $(2.083)$ & $(1.428)$ \\
\hline \multirow[t]{2}{*}{ PACE-ISIC 39} & -1.164 & & $0.360^{* *}$ & 0.238 & & $5.568^{* *}$ \\
\hline & $(1.336)$ & & (1.038) & $(0.916)$ & & $(0.727)$ \\
\hline Log-likelihood & 374.97 & 128.35 & 274.21 & 4570.00 & 200.83 & 340.31 \\
\hline No. of observations & 144 & 124 & 126 & 144 & 124 & 126 \\
\hline No. of cross-section units & 9 & 8 & 9 & 9 & 8 & 9 \\
\hline No. of time periods & 16 & 14 & 14 & 16 & 14 & 14 \\
\hline Parameters & 23 & 21 & 23 & 59 & 49 & 59 \\
\hline Homoskedasticity (LR) & $101.29^{* *}$ & $20.88^{* *}$ & $100.57^{* *}$ & & & \\
\hline Cross-correlation (LR) & & & & $165.47^{* *}$ & $144.95^{* *}$ & $132.21^{* *}$ \\
\hline
\end{tabular}

${ }^{\mathrm{a}}$ See the notes to Table 4

${ }^{\mathrm{b}}$ Data for ISIC 39 in the Netherlands are missing; see also footnote a to Table 2. 
Table A1: Standard industrial classifications, including pollution intensity and resource-base classification

\begin{tabular}{ccccc}
\hline $\begin{array}{c}\text { Standard Industrial } \\
\text { Classification (SIC) }\end{array}$ & $\begin{array}{c}\text { International } \\
\text { Standard Industrial } \\
\text { Classification } \\
\text { (ISIC) }\end{array}$ & $\begin{array}{c}\text { Standard } \\
\text { International Trade } \\
\text { Classification } \\
\text { (SITC) }\end{array}$ & $\begin{array}{c}\text { Resource-Based } \\
\text { (RB) or Non- } \\
\text { Resource-Based } \\
\text { (NRB) }\end{array}$ & $\begin{array}{c}\text { Pollution-Intensive } \\
\text { (PI) or Non- } \\
\text { Pollution-Intensive } \\
\text { (NPI) }\end{array}$ \\
\hline \hline 20 & 31 & 0111 & RB & NPI \\
21 & 31 & 1210 & NPI \\
22 & 32 & 6512 & NRB & NPI \\
24 & 33 & 2433 & RPI \\
25 & 33 & 2433 & RB & NPI \\
26 & 34 & 6411 & RB \\
27 & 34 & 6411 & RB & PI \\
28 & 35 & 599 & NRB & PI \\
29 & 35 & 2741 & NPI \\
30 & 35 & 2741 & RB & NPI \\
31 & 32 & 6113 & NRB & NPI \\
32 & 36 & 6651 & NRB & PI \\
33 & 37 & $6711-6714$ & NRB & PI \\
34 & 381 & $6960-6980$ & NRB & NPI \\
36 & 382 & 7115 & NRB & NPI \\
37 & 383 & 7221 & NRB & NPI \\
39 & 384 & 7353 & RB & NPI \\
\hline
\end{tabular}

